\title{
黒毛和種における胸最長筋内脂肪交雑粒子の細かさに関する 遺伝的パラメータの推定
}

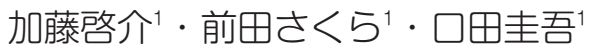 \\ 1 帯広畜産大学, 帯広市 080-8555
}

(2013. 5. 13 受付, 2013. 10. 1 受理)

\begin{abstract}
要 約 脂肪交雑粒子の細かさを評価した, 新細かさ指数の遺伝的パラメータの推定ならびに遺伝的趨勢 の調査を行うことを目的とした. 材料牛は, 2005 年 9 月から 2010 年 12 月にかけて北海道内の枝肉市場に 上場された黒毛和種 8,422 頭である. 枝肉左半丸第 6-7 肋骨間切開面の胸最長筋に関して, 画像解析を行った. 各画像解析形質について, 単形質アニマルモデルにより分散成分および遺伝率を推定した. また遺伝的関連 性の調査のため, 2 形質アニマルモデルにより遺伝および表型相関係数を推定した. 新細かさ指数の遺伝率 は 0.62 と高い值が推定された. 新細かさ指数はあらさ指数および従来法による細かさ指数との間に -0.01 および 0.60 の遺伝相関を示し, あらさ指数とは独立した形質, かつ従来法の細かさ指数と高い相関をもつ形 質であった. 近年の BMS ナンバ一重視の改良により脂肪交雑はあらくなる方へ向かっていることが推察さ れたが, 新細かさ指数とBMS ナンバーを改良に用いることで, あらい脂肪交雑粒子の増加を抑えながら脂 肪交雑の形状を望ましい方向に導くことが可能であると示唆された.
\end{abstract}

日本畜産学会報 85 (1), 21-26, 2014

わが国の牛枝肉の肉質評価においては, とりわけ脂肪交 雑を重視する傾向がある. また, 脂肪交雑粒子の量や形状 は格付に影響を与えるほか, 食味にも影響を及ぼすことが 報告されている. 脂肪交雑の特徵における客観的な評価に 関して, これまでに口田ら (1997) がロース芯における 高精細画像を撮影し, 画像解析値から評価値を算出した。 さらに口田ら（2002，2006）は脂肪交雑のあらさや細か さといつた, 脂肪交雑粒子の形状に関する指標を提案して いる. $\square \boxplus$ (2006) における細かさ指数は細かい粒子 $\left(0.01 \sim 0.5 \mathrm{~cm}^{2}\right)$ の個数をカウントしているため, 脂肪 交雑粒子が多く蓄積すると, 筋肉全体に脂肪交雑が存在し, 細かい粒子が存在する余地がなくなると推察した（浜崎ら 2009). すなわち, 一定の脂肪面積割合を超えると細かさ 指数が減少することが考えられる.

現在のBMS ナンバーは, シリコン樹脂から作製された 模型を基にしており, 模型の作製にあたつて脂肪面積割合 および脂肪交雑粒子の周囲長が考慮されている（中井 1987). 周囲長を利用し開発された新細かさ指数は, 小ザ シを高い精度で評価することが可能であることが確認され ている（口田と金井 2012）。したがって, 新細かさ指数 の遺伝的改良の指標としての可能性を探ることは重要であ る. また, 現在用いられている枝肉格付形質也画像解析形 質との関連性について調査することは, 総合的に価値の高 い枝肉を生産するために必要となる。
これまでの BMS ナンバーの評価は, 脂肪交雑の量を中 心としがちであり, 脂肪交雑のきめ細かさを改良の指標亡 できなかった時代が長く続いてきた. 特に近年では, 脂肪 交雑の量は十分であるが，その形状があらいといわれる種 雄牛も活躍した. 本研究では, 新細かさ指数に関して遺伝 的パラメー夕を推定し, 遺伝的改良の可能性を検討するこ と，ならびに遺伝的趨勢の調査を行うことを目的とした。

\section{材料および方法}

1. データ

分析には, 2005 年 9 月から 2010 年 12 月に北海道内の 枝肉市場に上場された黒毛和種のデータを用いた. 格付記 録をもつ個体のうち, 血統情報または肥育農家の記録がな いもの, 枝肉全体または口一ス芯に瑕疵のあるもの, 月齢 が平均 \pm 3 標準偏差から外れるものを削除した. また, 出 荷頭数が 5 頭未満の肥育農家からの個体を削除した. そ の結果, 分析に用いた最終的な個体数は 8,422 頭（去勢 : 6,122 頭, メス：2,300 頭）となった. 本研究において用 いた枝肉格付形質は, 枝肉重量, ロース芯面積, ばらの厚 さ, 皮下脂肪厚, 歩留基準値, BMS ナンバーおよびBCS ナンバーの7形質である。すすべての枝肉形質は, 牛枝肉 取引規格にしたがい（公社）日本食肉格付協会の格付員に よって評価された.

連絡者： $\square$ 田圭吾（fax：0155-49-5462，e-mail：kuchida@obihiro.ac.jp）

日畜会報 85 (1) : 21-26, 2014 
加藤 $\cdot$ 前 $\boxplus \cdot \square \boxplus$

\section{2. 画像解析形質}

ミラ一型牛枝肉撮影装置（HK-333；早坂理工，札幌） を用いて, 枝肉左半丸の第 6-7 助骨間切開面における高 精細画像を撮影し, 胸最長筋（口-ス芯）内の脂肪交雑の 量や形状に関する画像解析値を得た．分析に用いた画像解 析形質は, 脂肪面積割合, あらさ指数, 最大粒子のあらさ 指数, 細かさ指数, 新細かさ指数, 短径長径比およびロ一 ス芯複雑さの 7 形質である. ここであらさ指数はロース 芯内の脂肪交雑粒子全体のあらさの程度を示す指標であ る. 最大粒子のあらさ指数は, あらい脂肪交雑粒子のうち 面積が最大となる粒子のあらさを表すものである. 細かさ 指数は, 単位面積当たりに含まれる細かい脂肪交雑粒子 $\left(0.01 \sim 0.5 \mathrm{~cm}^{2}\right)$ の数を意味する. 新細かさ指数は, 口又芯内の脂肪交雑粒子の全周囲長を $\square$ 一ス芯面積の平方根 で除した值であり，値が大きいほど脂肪交雑が細かく入つ ていることを表している．短径長径比はロ一ス芯形状の円 形度合を示すものであり，1に近いほど円形に近く，值が 小さいほど扁平であることを示している。ロース芯複雑さ は口ース芯の筋肉形状の複雑さを示し, 值が大きいほど複 雑であることを示している.

画像解析形質についての詳細な定義也解析手順について は $\square \boxplus$ (2006) および口田と金井 (2012) に示される. これらの分析には高解像度 (3,600 万画素) の画像を扱う ことができ, 新細かさ指数を算出することが可能な專用の 画像解析ソフト (BeefAnalyzer-G; CS ソリューション, 札幌）を用いて行った.

\section{3. 遺伝的パラメータの推定}

それぞれの形質について，単形質アニマルモデルにより 分散成分および遺伝率を推定した。. 遺伝的パラメータの推 定に用いたモデルは以下の通りである：

$$
y_{i j k m}=Y_{i}+M_{j}+S_{k}+F_{1}+\beta\left(A_{i j k m}-\bar{A}\right)+a_{i j k m}+e_{j k k m}
$$

ここで, $y_{i k l m}$ は個体 $i j k l m$ の観測值, $Y_{i}$ は市場開催年の母 数効果 (6 水準), $M_{j}$ は市場開催月の母数効果 (12 水準), $S_{k}$ は性別の母数効果 (2 水準), $F_{1}$ は肥育農家の母数効果 (188 水準), $\beta$ は肥育月齢に対する 1 次の偏回帰係数, $A_{i j k m}$ は個体の肥育月齢, $\bar{A}$ は肥育月齢の全体平均, $a_{i j k m}$ は個体 $i j k / m$ に関する相加的遺伝効果 (变量効果), $e_{i j k m}$ は残差の变量効果である. 上記のモデルを行列表記すると
以下のようになる :

$$
\mathbf{y}=\mathbf{X b}+\mathbf{Z u}+\mathbf{e}
$$

ここで, y は観測值のべクトル, b は母数効果のべクトル, u は育種価のべクトル, e は残差のベクトルである. x お よびZは，それぞれの母数効果および育種価を $\mathrm{y}$ に結合 させる計画行列である. 分散共分散成分の推定および育種 価の予測には, AIREMLF90 およびBLUPF90 プログラ ム (Misztal 5 2002) を使用した. その際, 記録を持つ 個体から 5 世代祖まで遡り, 記録を持つ個体を含んだ総 個体数は 31,784 頭亡なった. また遺伝的媰勢を示すため に，種雄牛および繁殖雌牛の予測育種価を，それぞれ出生 年ごとに平均した值を用いた，なお，遺伝的趨勢を示すた めに用いた種雄牛および繁殖倠牛の個体は, 予測育種価の 正確度が 0.4 以上ある個体のみとした. 正確度の算出には, 以下の式を用いた：

$$
r_{i}=\sqrt{1-\frac{P E V_{i}}{\left(1+F_{i}\right) \sigma_{a}^{2}}}
$$

ここで, $r_{i}$ は $i$ 番目の個体の予測育種価の正確度, $P E V_{i}$ は $i$ 番目の個体の予測育種価の予測誤差分散, $F_{i}$ は $i$ 番目の 個体の近交係数， $\sigma_{a}^{2}$ は相加的遺伝分散である.

遺伝的関連性の調査のため, 上記で用いた数学モデルを 用い， 2 形質アニマルモデルによって遺伝および表型相関 係数を推定した.

\section{結果および考察}

枝肉格付形質の基本統計量, 分散成分および遺伝率を表 1 および表 2 に示した. 各形質の平均値は同地域における 調査結果亡同程度であった (中橋5 2012)。枝肉格付形 質における遺伝率は 0.32 0.67 の範囲であり, BCS ナ ンバーを除いて高い推定値を示した. Shojo ら (2006) は兵庫県および鳥取県の黒毛和種に関して, 枝肉重量の遺 伝率を 0.45 および 0.38 と報告し, 本研究の推定値 $(0.57)$ はこれらより高い値であった. BMS ナンバーの遺伝率は 0.67 であり, 同品種を扱つた川田ら (2003) や Shojo ら (2006) による推定值 (0.66 : 岩手県, 0.49 : 兵庫県, 0.61 ： 鳥取県）と比較して同程度または若干高い值であつた．褐 毛和種に対する Hirooka 5（1996）による0.40および 交雑種に対する Splan ら（2002）による 0.35 よりも高

Table 1 Basic statistics of carcass traits

\begin{tabular}{lrrrrr}
\hline \hline Trait & Mean \pm SD & Skewness & Kurtosis & Min & Max \\
\hline Carcass weight $(\mathrm{kg})$ & $453.3 \pm 58.1$ & -0.07 & 0.03 & 193.0 & 675.0 \\
Rib eye area $\left(\mathrm{cm}^{2}\right)$ & $57.3 \pm 8.2$ & 0.33 & 0.30 & 23.0 & 88.0 \\
Rib thickness $(\mathrm{cm})$ & $7.7 \pm 0.9$ & -0.07 & 0.47 & 3.0 & 11.6 \\
Subcutaneous fat thickness (cm) & $2.3 \pm 0.7$ & 0.71 & 0.75 & 0.2 & 5.6 \\
Yield estimate & $74.2 \pm 1.3$ & 0.09 & 0.26 & 69.3 & 79.9 \\
Beef marbling standard (BMS) & $5.6 \pm 2.2$ & 0.57 & -0.37 & 2.0 & 12.0 \\
Beef color standard (BCS) & $3.7 \pm 0.5$ & -0.37 & 0.10 & 1.0 & 6.0 \\
\hline
\end{tabular}


い値であった. したがつて BMSナンバーに関して，黒毛 和種は他の品種と比較して高い遺伝性をもつことが示され た.

表 3 および表 4 には, 画像解析形質の基本統計量, 分 散成分および遺伝率を示した. 脂肪面積割合の平均値は 46.0\% であり, Osawa 5（2008）の報告した 39.3\%よ り約 7\% 大きい値を示した. 本研究と Osawa 5 (2008) の記録の年代が異なり (本研究; 2005 年から 2010 年, Osawa 5; 2000 年か52004 年), 年代の新しい本研究 の表型値において脂肪交雑量の増加がみられた. 画像解析 形質の歪度から, 最大粒子のあらさ指数ならびにロ一ス芯 複雑さにおいて左に偏つた分布をすることが，また尖度に ついても, これら2形質で非常に大きな值を示したが, 他 の画像解析形質の歪度ならびに尖度は, 格付形質である ロ一ス芯面積のそれらと同程度であつた．最大粒子のあら さ指数およびロ一ス芯複雑さを除く画像解析形質の遺伝率
は中程度から高い値（0.33 0.79）であり, 脂肪交雑の 量や形状は表型值に対して遺伝的变異の割合が高 $<$, 十分 に遺伝的改良ができることが示された. 脂肪面積割合の遺 伝率は 0.79 であり, 同地域における過去の報告と比較し て, Osawa 5 (2008) の0.59 より高<, 中橋ら (2012) の 0.76 亡同程度の値が推定された. また，あらさ指数お よび最大粒子のあらさ指数の遺伝率は 0.60 および 0.08 であり,あらさ指数に関して中橋ら (2012) の推定值 0.50 より高く, 最大粒子のあらさ指数に関して同程度の値で あった．筋肉内には様々な大きさの脂肪粒子がランダムに 存在しているため, 最大粒子のあらさが突発的なものであ ることが考えられ，切開面の位置のばらつきが遺伝率の低 さにつながっていると推察される. 細かさ指数の遺伝率に 関して, 大澤ら (2008) および中橋ら (2012) による 0.43 および 0.38 と比較して 0.49 とほぼ同程度の值であった. また新細かさ指数の遺伝率は 0.62 と高い値を示した.

Table 2 Estimates of variance component and heritability $\left(h^{2}\right)$ of carcass traits

\begin{tabular}{lccc}
\hline \hline Trait & $\begin{array}{c}\text { Genetic } \\
\text { variance }\end{array}$ & $\begin{array}{c}\text { Residual } \\
\text { variance }\end{array}$ & $h^{2} \pm$ SE \\
\hline Carcass weight & 1260.9 & 935.7 & $0.57 \pm 0.05$ \\
Rib eye area & 32.5 & 31.0 & $0.51 \pm 0.05$ \\
Rib thickness & 0.31 & 0.34 & $0.48 \pm 0.05$ \\
Subcutaneous fat thickness & 0.30 & 0.18 & $0.62 \pm 0.05$ \\
Yield estimate & 1.01 & 0.73 & $0.58 \pm 0.05$ \\
Beef marbling standard (BMS) & 2.71 & 1.35 & $0.67 \pm 0.05$ \\
Beef color standard (BCS) & 0.09 & 0.18 & $0.32 \pm 0.04$ \\
\hline
\end{tabular}

Table 3 Basic statistics of image analysis traits

\begin{tabular}{|c|c|c|c|c|c|}
\hline Trait & Mean \pm SD & Skewness & Kurtosis & Min & Max \\
\hline Marbling percent (\%) & $46.0 \pm 8.3$ & -0.29 & -0.20 & 14.9 & 69.5 \\
\hline Coarseness index of marbling (\%) & $16.3 \pm 5.0$ & 0.30 & 0.32 & 1.5 & 49.6 \\
\hline Coarseness index of the largest marbling (\%) & $4.0 \pm 2.4$ & 2.30 & 13.55 & 0.3 & 42.6 \\
\hline Fineness index of marbling (count/ $\left.\mathrm{cm}^{2}\right)$ & $3.3 \pm 0.5$ & 0.12 & -0.01 & 0.8 & 5.1 \\
\hline New fineness index of marbling (pixel/cm) & $7.7 \pm 1.1$ & 0.02 & 0.06 & 3.5 & 12.0 \\
\hline Minor-major axis ratio & $0.66 \pm 0.07$ & 0.24 & 0.15 & 0.38 & 0.95 \\
\hline Complexity of rib eye shape & $1.10 \pm 0.03$ & 2.00 & 6.78 & 1.05 & 1.39 \\
\hline
\end{tabular}

Table 4 Estimates of variance component and heritability $\left(h^{2}\right)$ of image analysis traits

\begin{tabular}{lccc}
\hline \hline Trait & $\begin{array}{c}\text { Genetic } \\
\text { variance }\end{array}$ & $\begin{array}{c}\text { Residual } \\
\text { variance }\end{array}$ & $h^{2} \pm$ SE \\
\hline Marbling percent & 46.0 & 12.1 & $0.79 \pm 0.05$ \\
Coarseness index of marbling & 13.4 & 8.8 & $0.60 \pm 0.05$ \\
Coarseness index of the largest marbling & 0.44 & 5.02 & $0.08 \pm 0.02$ \\
Fineness index of marbling & 0.13 & 0.14 & $0.49 \pm 0.05$ \\
New fineness index of marbling & 0.69 & 0.42 & $0.62 \pm 0.05$ \\
Minor-major axis ratio *100 & 15.24 & 30.74 & $0.33 \pm 0.04$ \\
Complexity of rib eye shape *100 & 1.17 & 8.06 & $0.13 \pm 0.04$ \\
\hline
\end{tabular}


表 5 には, 新細かさ指数と各枝肉格付形質間の遺伝お よび表型相関係数を示した。新細かさ指数は枝肉重量およ びばらの厚さと低い正の遺伝相関（ともに 0.20）があり, 皮下脂肪厚と低い負の遺伝相関（-0.25）であつたため, 新細かさ指数を改良すると枝肉の充実度が望ましい方へ向 かうことが示された. そのため, 歩留基準値との高い遺伝 相関（0.59）が推定されたと考えられる. BMSナンバー との遺伝相関は 0.69 と高い相関が得られた. BMSナン バ一の基準となっている 12 段階のシリコン樹脂の模型の 作製時, 基準として脂肪面積割合が採用されるとともに, 脂肪交雑粒子の周囲長も利用されたことから, 周囲長を取 り入れた新細かさ指数はBMS ナンバーと高し相関を示し たことが示唆される. 新細かさ指数と他の画像解析形質間 の遺伝および表型相関係数を表 6 に示した. 従来法の細 かさ指数と, あらさ指数ならびに新細かさ指数との遺伝相 関はそれぞれー0.93 (表なし)，0.60であるのに対し，新 細かさ指数とあらさ指数との遺伝相関はー0.01 とほぼ無 相関であつた. また脂肪面積割合とあらさ指数ならびに新 細かさ指数間の遺伝相関はそれぞれ 0.70 (表なし), 0.62 であり，双方とも脂肪の量と高い遺伝的関連性があるもの の, 脂肪交雑のあらさと新細かさ指数で示される脂肪交雑 の細かさは独立した形質であるといえる，新細かさ指数と 最大粒子のあらさ指数間の遺伝相関は, -0.37 と中程度 の負の遺伝相関を示した. 最大粒子のあらさ指数は口ース 芯内において極端に大きな脂肪が入り込んでいる場合, 高 い値を示す。ロース芯内に大きな脂肪があると細かい脂肪
の入る余地が小さいことが, 新細かさ指数との間に負の関 連性を示した原因と考えられる。新細かさ指数と口一ス芯 形状の形質間に関して, 短径長径比との間には 0.27 の遺 伝相関があつたが, ロ一ス芯複雑さとの間では無相関だつ た (0.01). 一般に, ロース芯は扁平な形状よりたわら型 が好まれ，ロ一ス芯形状は複䧱でない方が好まれる。新細 かさ指数の改良を進めることで，ロ一ス芯形状に影響を与 えず，望ましいとされるたわら型へ改良ができることが示 唆された.

図 1 には, 種雄牛および繁殖雌牛に関する脂肪面積割 合および新細かさ指数の遺伝的趨勢を示した. 種雄牛の平 均予測育種価の推移は繁殖雌牛に比べ出生年当たりの個体 数が少ないため, 年ごとの変動が大きかつた. 脂肪面積割 合および新細かさ指数の平均予測育種価は 1990 年頃まで はほぼ横ばいだが, それ以降増加傾向を示した。牛枝肉取 引規格は1988 年に改正され, 枝肉外観による一元評価か ら量と質の二元評価になるとともに脂肪交雑の評価が現在 の 12 段階となつた. また以前から脂肪交雑の改良は行わ れていたが, 1991 年の牛肉輸入自由化以降輸入牛肉に対 抗するために, より脂肪交雑へ重点を置いた改良が行われ るようになった. さらに1991 年には, フィールド情報を 活用しアニマルモデル BLUP 法の導入がなされた（向井 2009).己のような背景から 1990 年以降, 脂肪面積割合 の育種価が急速に増加したと考えられる.

新細かさ指数および脂肪面積割合に関して，繁殖雌牛の 遺伝的趨勢を比較するために，それぞれの育種価を標準化

Table 5 Genetic and phenotypic correlation estimates between new fineness index of marbling and carcass traits

\begin{tabular}{lcc}
\hline \hline Trait & $\begin{array}{c}\text { Genetic } \\
\text { correlation }\end{array}$ & $\begin{array}{c}\text { Phenotypic } \\
\text { correlation }\end{array}$ \\
\hline Carcass weight & 0.20 & 0.18 \\
Rib eye area & 0.64 & 0.51 \\
Rib thickness & 0.20 & 0.16 \\
Subcutaneous fat thickness & -0.25 & -0.15 \\
Yield estimate & 0.59 & 0.46 \\
Beef marbling standard (BMS) & 0.69 & 0.62 \\
Beef color standard (BCS) & -0.26 & -0.19 \\
\hline
\end{tabular}

Table 6 Genetic and phenotypic correlation estimates between new fineness index of marbling and other image analysis traits

\begin{tabular}{lcc}
\hline \hline Trait & $\begin{array}{c}\text { Genetic } \\
\text { correlation }\end{array}$ & $\begin{array}{c}\text { Phenotypic } \\
\text { correlation }\end{array}$ \\
\hline Marbling percent & 0.62 & 0.61 \\
Coarseness index of marbling & -0.01 & -0.12 \\
Coarseness index of the largest marbling & -0.37 & -0.23 \\
Fineness index of marbling & 0.60 & 0.57 \\
Minor-major axis ratio & 0.27 & 0.15 \\
Complexity of rib eye shape & 0.01 & 0.04 \\
\hline
\end{tabular}




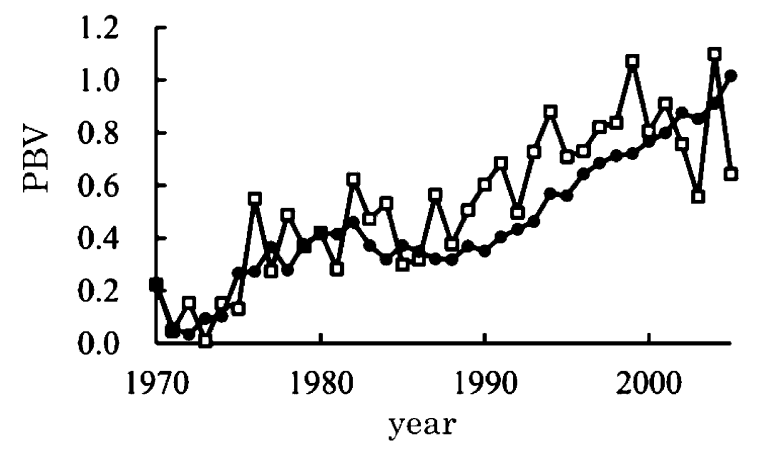

a ) New fineness index of marbling

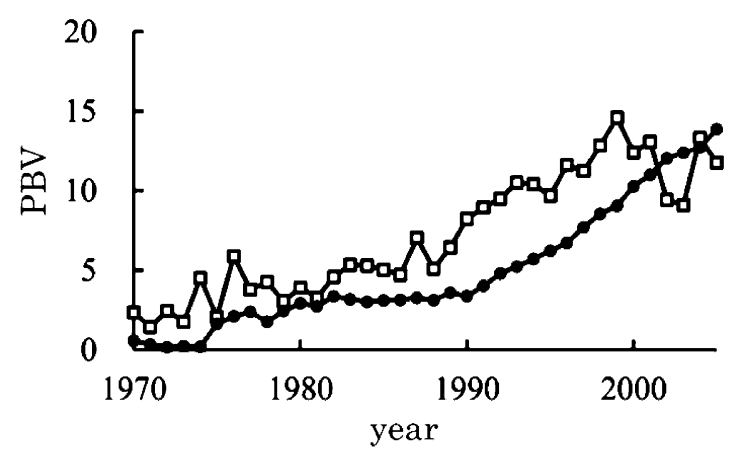

b ) Marbling percent

Figure 1 Genetic trend of the new fineness index of marbling (a) and marbling percent (b) for sire $(\square)$ and dam (O) since 1970.

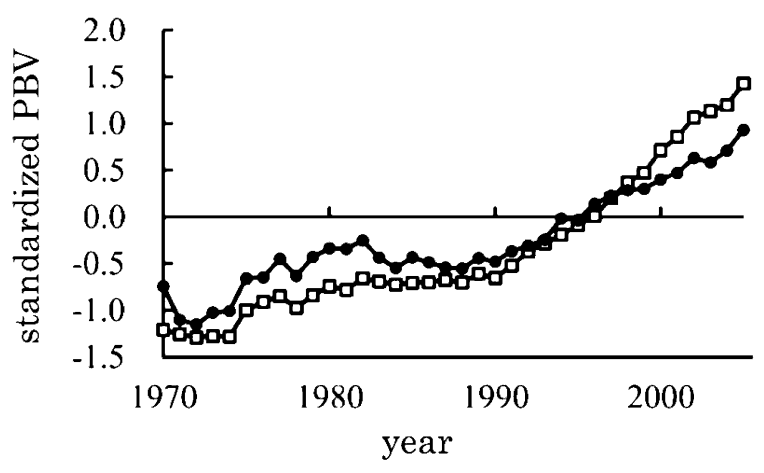

Figure 2 The progress of standardized predict breeding value for new fineness index $(0)$ and marbling percent $(\square)$.

し年ごとに平均した値の推移を図 2 に示した. 繁殖䊒牛に 関して, 新細かさ指数の標準化した平均予測育種価は, 脂 肪面積割合のそれと比較し緩やかな増加であった. 2005 年において脂肪面積割合の標準化予測育種価の平均は 1.4 であるのに対し, 同年の新細かさ指数のそれは 0.9 であり, 二つの形質間には高い遺伝相関があるにもかかわらず, 約 0.5 標準偏差の差が認められた．改良の重点は主にBMS ナンバーに置かれたことから，より BMS ナンバーと関係
の強い脂肪面積割合の遺伝的趨勢に現れ，小ザシの改良速 度が脂肪面積割合のそれに比べて劣ることが明らかとなっ た. 肉質に関して BMS ナンバーのみを用いた近年の改良 は, あらい脂肪交雑粒子を増加させる可能性があり，改良 にあたって留意する必要がある.

これまでのBMS ナンバーを重視した改良は, 脂肪面積 割合の遺伝的趨勢に示されたように脂肪交雑の量を急激に 増加させた．これに伴いひげ状に存在する小ザシも増加し てきたが, 同時にあらい脂肪交雑の増加が懸念される. 本 研究で用いた脂肪面積割合や新細かさ指数を BMS ナン バーとともに改良形質とすることで，あらい脂肪交雑粒子 の増加を抑えながら脂肪交雑の形状を望ましい方向へ導く 可能性が示唆された.

\section{文献}

浜崎陽子, 中橋良信, 村澤七月, $\square$ 田圭吾. 2009. 画像解析によ る黒毛和種および黒毛和種×ホルスタイン種における BMS ナンバーの評価に影響を与える要因の調査. 日本畜産学会報 80, 333-340.

Hirooka H, Groen AF, Matsumoto M. 1996. Genetic parameters for growth and carcass traits in Japanese Brown cattle estimated from field records. Journal of Animal Science 74, 2112-2116.

川田啓介, 兼松重任, 黒澤弥悦, 揖斐隆之, 佐々木義之. 2003. 岩手県南地方における黒毛和種集団の産肉性形質に関する統 計遺伝学的解析. 日本畜産学会報 74, 187-193.

$\square$ 田圭吾, 金井俊男. 2012. 食肉の脂肪交雑の評価方法. 特願 2012-217934

口田圭吾, 栗原晃子, 鈴木三義, 三好俊三. 1997. 画像解析によ るロ一ス芯断面内脂肪交雑粒子に関する客観的評価法. 日本 畜産学会報 68, 878-882.

口田圭吾, 大澤剛史, 堀 武司, 小高仁重, 丸山 新. 2006. 画 像解析による牛枝肉横断面の評価とその遺伝. 動物遺伝育種 研究 34, 45-52.

口田圭吾, 鈴木三義, 三好俊三. 2002. 画像解析による牛最長筋 内脂肪交雑粒子のあらさに関する評価法の㛟討。日本畜産学 会報 73，9-17

Misztal I, Tsuruta S, Strabel T, Auvray B, Druet T, Lee D. 2002. BLUPF90 and related programs (BGF90). Proceeding of the 7th World Congress on Genetics Applied to Livestock Production, Montpellier, France, CD-ROM Communication 28, 07.

向井文雄. 2009. 黒毛和種の育種改良の現状と課題。家畜育種研 究会報 17, 34-64.

中橋良信, 由佐哲朗, 增田 豊, 日高 智, 口田圭吾. 2012. 黒 毛和種におけるロース芯内交雑脂肪の脂肪酸組成に関する遺 伝的パラメータの推定. 日本畜産学会報 83, 29-34.

中井博康. 1987. 食肉の理化学的特性による品質評価基準の確立. 農林水産技術会議事務局研究成果 193，106-122.

大澤剛史，日高 智，加藤浩二， 口田圭吾。2008b。黒毛和種枝 肉横断面の画像解析形質と発育性ならびに飼料利用性間の遺 伝的関連性. 日本畜産学会報 79, 193-201.

Osawa T, Kuchida K, Hidaka S, Kato T. 2008a. Genetic parameters for image analysis traits on $M$. Iongissimus thoracis and $M$. trapezius of carcass cross section in Japanese Black steers. Journal of Animal Science $\mathbf{8 6}$. 40-46. 
Shojo M, Okanishi T, Anada K, Oyama K, Mukai F. 2006. Genetic analysis of calf market weight and carcass traits in Japanese Black cattle. Journal of Animal Science 84, 2617-2622.

Splan RK, Cundiff LV, Dikeman ME, Van Vleck LD. 2002.
Estimates of parameters between direct and maternal genetic effects for weaning weight and direct and direct genetic effects for carcass traits in crossbred cattle. Journal of Animal Science 80, 3107-3111.

\title{
Genetic parameters for fineness of marbling in M. longissimus thoracis of Japanese Black cattle
}

\author{
Keisuke KATO', Sakura MAEDA ${ }^{1}$ and Keigo KUCHIDA ${ }^{1}$ \\ ${ }^{1}$ Obihiro University of Agriculture and Veterinary Medicine, Obihiro 080-8555, Japan \\ Corresponding : Keigo KUCHIDA (fax : +81 (0) 155-49-5462, e-mail : kuchida@obihiro.ac.jp)
}

This study aimed at estimating genetic parameters and investigating genetic trend for new fineness index of marbling. Carcass data were obtained from Japanese Black cattle $(n=8,422)$ shipped to a meat processing plant in Hokkaido in September of 2005 to December of 2010. Digital images around the rib eye at the 6th and 7th rib section were taken and analyzed. Genetic analyses were conducted to estimate heritabilities for each image analysis trait and genetic correlations between new fineness index of marbling (NFI) and other image analysis traits using single/multiple trait animal models. The estimated heritability of NFI was 0.62 . This indicates that NFI is available as genetic improvement trait. Genetic correlations between NFI and coarseness index of marbling or fineness index of marbling (conventional) were -0.01 and 0.60 , so $\mathrm{NFI}$ is independent of coarseness index of marbling and correlated with conventional fineness index of marbling. Genetic correlations between NFI and marbling percent or BMS were 0.62 and 0.69 , respectively. It was suggested that the improvement of BMS resulted in changing NFI for the better. Standardized predict breeding value (SPEV) of NFI and MP for dam increased since 1990. However, SPEV of these traits in 2005 were 0.9 and 1.4, respectively, the difference was 0.5 despite the high genetic correlation of NFI and MP. Thus, genetic improvement of NFI was inferior as compared with that of MP. The improvement with a focus on BMS results in an increase in coarseness marbling of rib eye area.

Nihon Chikusan Gakkaiho 85 (1), 21-26, 2014

Key words : fineness of marbling, genetic parameter, image analysis. 